\title{
HYDROGEN ION CONCENTRATION OF THE DUODENAL CONTENTS UNDER FASTING CONDITIONS IN NORMAL PERSONS AND IN PATIENTS WITH DUODENAL ULCER: A COMPARATIVE STUDY ${ }^{1}$
}

\author{
BY R. WYNN KEARNEY, MANDRED W. COMFORT, AND ARNOLD E. OSTERBERG \\ (From the Division of Biochemistry, The Mayo Foundation and the Division of Medicine, \\ The Mayo Clinic, Rochester, Minn.)
}

(Received for publication October 28, 1940)

The experimental surgeon, working on animals, has contributed materially to our fund of. information concerning the formation of peptic ulcer. $\mathrm{He}$ has shown that the withdrawal of alkaline duodenal secretion from the particular portion of the intestinal tract into which the stomach empties, and exposure of the intestinal mucosa to acid gastric chyme for abnormally long periods, lead to the formation of ulcer in a high percentage of experiments regardless of the surgical procedure employed ( 1 to 7 ). It has been concluded from these experiments that the hydrochloric acid poured from the stomach into the duodenum traumatizes the duodenal mucosa by chemical and mechanical action in such a way as to produce the ulcer, even though the existence of the conditions experimentally induced in animals has not been demonstrated in patients with duodenal ulcer.

In reality, the pathologic physiology underlying formation of duodenal ulcer has not been studied to any great extent in man. Only one fact has been clearly demonstrated, namely, that the average gastric acidity of patients with duodenal ulcers is greater than that of normal persons $(8,9)$. It has not been shown that the entrance of more than average amounts of acid from the stomach into the duodenum in patients with duodenal ulcer creates an abnormally acid condition in the duodenum.

Some effort has been made to determine the hydrogen ion concentration of the duodenal contents of normal persons but the information gained has been fragmentary (10 to 16$)$. Determination of hydrogen ion values usually has been on single specimens obtained by duodenal intubation at long intervals or on block samples

1 Abridgment of thesis submitted by Dr. Kearney to the Faculty of The Graduate School of The University of Minnesota in partial fulfillment of the requirements for the degree of M.S. in Surgery. collected over varying periods. In none of these observations has the behavior of values for $\mathrm{pH}$ been studied in relation to gastric acidity. Even less is known about the hydrogen ion concentration of the duodenal contents of patients with duodenal ulcer. Morton's work is the first and only attempt to study this problem so far as we can find (17). He reported that free acid was present in the duodenal contents of patients with peptic ulcer, whereas free hydrochloric acid was not recovered from the duodenal contents of persons without ulcer. His determinations were made one hour after an Ewald test meal and on single specimens obtained with the duodenal tube. These data obviously give an incomplete picture of the changes in hydrogen ion concentration of normal persons and of patients with duodenal ulcer.

In this investigation we propose to study the hydrogen ion concentration of the duodenal contents of normal persons with varying degrees of gastric acidity in order to obtain a norm, and of patients with duodenal ulcer in the hope of finding some variation from the normal behavior of the hydrogen ion concentration of the duodenal contents which might have some bearing on the causation of ulcer.

\section{MATERIAL}

A total of thirty-four successful series of observations was performed on seven normal subjects, and twenty successful series of observations on thirteen patients with duodenal ulcer. The duration of the observations on normal subjects totaled eighty-seven hours and on patients with duodenal ulcer fifty-one hours.

\section{METHODS}

The duodenal tube was introduced into the duodenum after a fast of twelve hours. That the tip of the tube was located in the second portion of the duodenum was confirmed by roentgenologic examination. The duodenal 
contents were withdrawn continuously, a negative pressure of 14 inches $(36 \mathrm{~cm}$.) of water being used. A flow of duodenal contents sufficient for determination of the values for hydrogen ion concentration was obtained at all times with the exception of a few short intervals during a total of more than 130 hours of continuous aspiration. In the early observations the $\mathrm{pH}$ value was determined on block samples at five- to ten-minute intervals by means of a platinum quinhydrone electrode with a Leeds-Northrup potentiometer. In a majority of the determinations, however, a Cameron glass bulb electrode was used; in these observations the contents from the duodenum were drawn through a small chamber into which the glass bulb electrode projected and at twominute intervals the flow was interrupted for a few seconds sufficient to make the determination.

\section{Possible errors in data arising from technic}

The constant removal of duodenal contents shortens the time during which the hydrochloric acid normally remains in the duodenal cavity. This may diminish the response of the hormonal mechanism that stimulates the flow of bile and pancreatic juice or that which depresses the secretion of acid by the stomach. The $\mathrm{pH}$ values obtained may not, therefore, be the $\mathrm{pH}$ values in the undisturbed fasting duodenal contents. However, any error arising from the technic will affect in a similar manner values obtained from normal persons and from patients with duodenal ulcer and should not affect the validity of data for comparison of the behavior of values in the two groups of patients.

\section{Data from normal persons}

The gastric contents of normal Subject 1 did not contain free hydrochloric acid after stimulation either with the water carbohydrate meal or with histamine (Table I). During two series of observations lasting a total of nearly three hours, $\mathrm{pH}$ values varied from 6.7 to 7.7 .

The gastric contents of normal Subject 2 obtained under fasting conditions or after stimulation with the water carbohydrate meal did not contain free hydrochloric acid, but after stimulation with histamine in doses of $0.1 \mathrm{mgm}$. per $10 \mathrm{kgm}$. of body weight the free hydrochloric acid attained a value of 26 clinical units and the $129 \mathrm{cc}$. of gastric contents recovered during the sixty minutes following stimulation contained $25 \mathrm{cc}$. of tenth normal hydrochloric acid (Table I). In spite of the fact that the stomach of this subject was able to secrete acid in small quantities after stimulation with histamine, the $\mathrm{pH}$ values fluctuated from 6.0 to 7.5 and did not fall below 6 during the entire period of the observations (three hours), thus remaining in practically the same range as did the values obtained from normal Subject 1 with true anacidity.

The gastric secretory activities in normal Sub-

TABLE I

The gastric secretory activity and the percentage of total duration of observations during which various pH values of duodena contents were obtained in seven normal subjects

\begin{tabular}{|c|c|c|c|c|c|c|c|c|c|c|c|c|c|c|c|c|}
\hline \multirow[b]{2}{*}{ Subject } & \multicolumn{2}{|c|}{$\begin{array}{l}\text { Modified } \\
\text { Ewald } \\
\text { meal* }\end{array}$} & \multicolumn{3}{|c|}{$\begin{array}{c}\text { Stimulation } \\
\text { with } \\
\text { histamine† }\end{array}$} & \multirow{2}{*}{$\begin{array}{l}\text { Num- } \\
\text { ber } \\
\text { of } \\
\text { series } \\
\text { of } \\
\text { obser- } \\
\text { vations }\end{array}$} & \multirow{2}{*}{$\begin{array}{c}\text { Total } \\
\text { dura- } \\
\text { tion } \\
\text { in } \\
\text { min- } \\
\text { utes }\end{array}$} & \multicolumn{9}{|c|}{$\begin{array}{l}\text { Percentages of total duration of observations during which various } \\
\text { pH values of duodenal contents were obtained }\end{array}$} \\
\hline & $\begin{array}{c}\text { Total } \\
\text { acid- } \\
\text { ity }\end{array}$ & $\begin{array}{c}\text { Free } \\
\text { acid- } \\
\text { ity }\end{array}$ & $\begin{array}{l}\text { Vol- } \\
\text { ume }\end{array}$ & $\begin{array}{c}\text { Total } \\
\text { cc. } \\
\text { tenth } \\
\text { normal } \\
\mathrm{HCl}\end{array}$ & $\begin{array}{c}\text { High- } \\
\text { est } \\
\text { con- } \\
\text { cen- } \\
\text { tration } \\
\text { free } \\
\text { HCl }\end{array}$ & & & $\begin{array}{l}1.1 \\
\text { to } \\
2\end{array}$ & $\begin{array}{c}2.1 \\
\text { to } \\
3\end{array}$ & $\begin{array}{c}3.1 \\
\text { to } \\
4\end{array}$ & 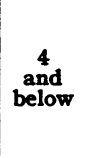 & $\begin{array}{c}4.1 \\
\text { to } \\
5\end{array}$ & $\begin{array}{c}5.1 \\
\text { to } \\
6\end{array}$ & $\begin{array}{c}6 \\
\text { and } \\
\text { below }\end{array}$ & $\begin{array}{c}6.1 \\
\text { to } \\
7\end{array}$ & $\begin{array}{c}7.1 \\
\text { to } \\
7.9\end{array}$ \\
\hline $\begin{array}{l}1 \\
2 \\
3 \\
4 \\
5 \\
6 \\
7\end{array}$ & $\begin{array}{r}6 \\
6 \\
54 \\
50 \\
68 \\
70 \\
96\end{array}$ & $\begin{array}{r}0 \\
0 \\
48 \\
38 \\
56 \\
50 \\
80\end{array}$ & $\begin{array}{r}c c . \\
129 \\
86 \\
140 \\
164 \\
160 \\
195\end{array}$ & $\begin{array}{r}0 \\
25 \\
99 \\
96 \\
95 \\
123 \\
196\end{array}$ & $\begin{array}{r}0 \\
26 \\
112 \\
94 \\
70 \\
86 \\
120\end{array}$ & $\begin{array}{l}2 \\
1 \\
9 \\
3 \\
9 \\
4 \\
6\end{array}$ & $\begin{array}{r}168 \\
182 \\
1568 \\
383 \\
1448 \\
709 \\
751\end{array}$ & $\begin{array}{l}0 \\
0 \\
0 \\
0 \\
5.2 \\
0 \\
7.5\end{array}$ & $\begin{array}{c}0 \\
0 \\
0 \\
4.2 \\
7.6 \\
7.8 \\
11.3\end{array}$ & $\begin{array}{l}0 \\
0 \\
2.7 \\
7.8 \\
8.3 \\
14.7 \\
14.0\end{array}$ & $\begin{array}{c}0 \\
0 \\
2.7 \\
12.0 \\
21.1 \\
22.5 \\
32.8\end{array}$ & $\begin{array}{l}0 \\
0 \\
6.6 \\
7.3 \\
11.6 \\
17.1 \\
13.3\end{array}$ & $\begin{array}{c}0 \\
0 \\
48.4 \\
32.9 \\
45.2 \\
19.4 \\
15.2\end{array}$ & $\begin{array}{c}0 \\
0 \\
57.7 \\
52.2 \\
77.9 \\
59.0 \\
61.3\end{array}$ & $\begin{array}{l}29.7 \\
85.8 \\
38.0 \\
37.4 \\
22.0 \\
32.5 \\
34.0\end{array}$ & $\begin{array}{r}70.3 \\
14.2 \\
4.3 \\
10.4 \\
0.1 \\
8.5 \\
4.7\end{array}$ \\
\hline $\begin{array}{l}\text { Average } \\
3,4,5, \\
6 \text { and } 7\end{array}$ & & & & & & $34 \ddagger$ & $5209 \ddagger$ & 2.54 & 6.18 & 9.50 & 18.22 & 11.18 & 32.22 & 61.62 & 32.78 & 5.60 \\
\hline
\end{tabular}

* Values in clinical units one hour after ingestion of meal.

$\dagger$ Values obtained in the one-hour period after stimulation. 
jects $3,4,5$ and 6 were similar to one another and moderate (Table I). The behavior of the $\mathrm{pH}$ values of the duodenal contents in these subjects is illustrated in Figure 1. The roentgenograms showed the tip of the tube to be in the second portion of the duodenum; the glass bulb electrode was used. During the first eight minutes a slightly cloudy amber fluid with $\mathrm{pH}$ values varying between 6.7 and 4.5 was obtained. The contents then changed in gross appearance, becoming very cloudy and containing much gastric secretion. The $\mathrm{pH}$ values dropped below 3 within ten minutes; then the gross appearance of the duodenal contents again changed, becoming amber, and the $\mathrm{pH}$ values rose to 5.5 , a level at which they remained for the next sixty minutes. The material then grossly appeared to be a mixture of bile and gastric contents and the $\mathrm{pH}$ values dropped to about 3 or below for ten minutes; then a flow of clear amber fluid occurred and the $\mathrm{pH}$ values rose to 6.5 and remained at about this level until the end of the observation was reached.

The flow of acid gastric material from the duodenal tube was followed promptly by a flow of amber colored fluid in this and other observations on these subjects. This means that the entrance of acid gastric material into the duodenum promptly evoked a secretion of bile and pancreatic juice. The frequency and duration of the periods during which acid gastric material was obtained from the duodenum varied considerably. However, the excursions of $\mathrm{pH}$ values below 4 never lasted more than twenty minutes and 78 per cent of the excursions lasted ten minutes or less. The tendency for the values to be maintained in the upper less acid levels is definite. The percentage of duration of each observation on each subject during which the $\mathrm{pH}$ values were below 4 was greater than 25 in only one observation (reaching 37 per cent). Moreover, the values remained above $6,42.3,47.8,22.1$ and 41 per cent of the time and fell below 4 only 2.7, 12.0, 21.1 and 22.5 per cent of the total time during which values were determined, respectively, in Cases 3, 4, 5 and 6 (Table I). In this connection it is interesting that the $\mathrm{pH}$ values fell below 2 in Case 5 only and then only for 5.2 per cent of the total time during which values were determined in this case.

It appears that the stomachs of these normal persons (Cases 3, 4, 5 and 6) were emptying acid into the duodenum only a little more than half the time. If free hydrochloric acid was entering the duodenum a greater part of the time than the figures in Table I indicate, the duodenal contents were present in such quantities and of such alkalinity that the quantity of free acid entering the duodenum could depress the $\mathrm{pH}$ values below 6 only a little more than half of the time. It also appears that the response of outflow of bile and pancreatic juice to the entrance of highly acid gastric contents into the duodenum was prompt and in quantities sufficient to prevent the existence of free hydrochloric acid $(\mathrm{pH}$ value below 4 ) in the lumen of the duodenum for long periods. Such behavior may be considered normal for healthy persons whose stomachs are capable of secreting the more moderate amounts of acid.

The free hydrochloric acid was obtained from

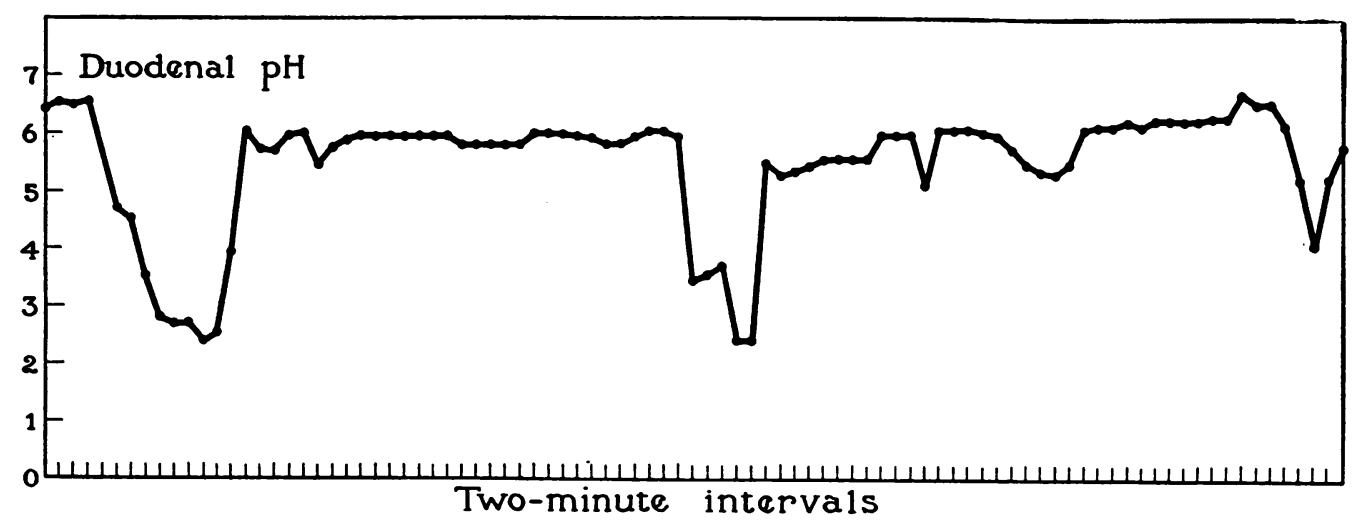

Fig. 1. The Typical Behavior of Values for the Hydrogen Ion Concentration of the Duodenal Contents of Normal Persons with Average Gastric Secretory Activity 
the stomach of normal Subject 7 in quantities well above the average for normal persons (Table I). Seventy per cent of the excursions of the $\mathrm{pH}$ values of the duodenal contents below 4 lasted ten minutes or less, a figure that is not very different from that (78) obtained in Cases 3, 4, 5 and 6. However, the excursions of $\mathrm{pH}$ values below 4 lasted longer than twenty minutes in three instances (twenty-five, thirty and thirty-two minutes). The percentage of duration of each observation during which the $\mathrm{pH}$ values were below 4 varied more widely in Subject 7 than in Subjects $3,4,5$ and 6 , the percentage being greater than 25 in three of six observations, whereas it was above 25 in only one of twenty-four observations in Subjects 3, 4, 5 and 6. The percentages of duration of observations 3 and 6, Subject 7, during which the $\mathrm{pH}$ values were below 4 , were 50 and 51 , respectively. Such percentages are seen in some subjects with duodenal ulcer but are far below those seen in most cases with this disease. The $\mathrm{pH}$ values were below 4 in a slightly greater percentage of the duration of all observations on Subject 7 (32.8 per cent) than in Cases $3,4,5$ and 6 (2.7 to 22.5 per cent, Table I).

In other words, a greater secretion of acid by the stomach of normal Subject 7 than by the stomachs of normal Subjects 3, 4, 5 and 6 caused the duodenal contents of Subject 7 to be slightly more acid than those from normal Subjects 3, 4, 5 and 6 . In spite of these differences, the $\mathrm{pH}$ values remained above 6 about the same percentage of time in Subject 7, as noted in the observations of Subjects $3,4,5$ and 6 , and the behavior of the $\mathrm{pH}$ values seen in Subject 7 was not far different from that encountered in normal Subjects $3,4,5$ and 6 . For the most part, the neutralizing and diluting mechanism in the duodenum of Subject 7 was almost as competent to take care of the larger amounts of acid pouring into the duodenum as was that of Subjects $3,4,5$ and 6 to take care of the smaller amounts of acid entering their duodenums.

A constant, direct relationship cannot be demonstrated in these seven normal subjects between the gastric secretory activity and the behavior for $\mathrm{pH}$ values of the duodenal contents. It is obvious, however, that the behavior of the $\mathrm{pH}$ values of the duodenal contents is distinctly different in the case with low gastric secretory activity (Case
2) from the behavior of the $\mathrm{pH}$ values of the duodenal contents in the cases with about average gastric secretory activity (Cases 3, 4, 5 and 6). Moreover, the behavior of $\mathrm{pH}$ values of the duodenal contents is at least slightly different in the cases with average gastric acidity from that in the case with high gastric acidity (Case 7). The amount of acid gastric juice entering the duodenum seemingly does influence the behavior of the $\mathrm{pH}$ values in normal subjects.

\section{Data from patients with duodenal ulcer}

The behavior of the $\mathrm{pH}$ of the duodenal contents in Subject 8 with duodenal ulcer (Table II) resembles the behavior seen in the normal person with anacidity (Case 1 , Table I) or that seen in the normal person with very low gastric acidity (Case 2, Table I). The gastric contents of Subject 8 contained 44 units of free acid after the modified Ewald meal but did not contain any free acid in the fasting state. This may have some bearing on the occurrence of the high $\mathrm{pH}$ values (above 6.5) in the three hours during which determinations were carried out and on the apparent failure of acid to enter the duodenum during this period.

The behavior of the $\mathrm{pH}$ values in Subject 9 with duodenal ulcer is similar to that seen in the normal individual with average gastric secretory activity in spite of the ability of the stomach of this patient to secrete acid in amounts greater than average. The diluting and neutralizing mechanism of the duodenum appears capable of caring for any excess secretion of acid that may have occurred in this series of observations.

In the first series of observations on Subject 10 with duodenal ulcer, the $\mathrm{pH}$ values were below 2,81 per cent of the time, whereas in the second series of observations on the same subject the values were above 6,100 per cent of the time. Such marked variability in the $\mathrm{pH}$ values was unusual; in other cases in which two series of observations were made the distributions of $\mathrm{pH}$ values were similar.

The behavior of the $\mathrm{pH}$ values in subjects with duodenal ulcer (Subjects 11 to 20 , inclusive) was remarkably consistent and similar. The behavior is illustrated in the observations on Subject 16 with duodenal ulcer (Figure 2). The duodenal contents at the start obviously contained much 
TABLE II

The gastric secretory activity and the percentage of total duration of observations during which various $p H$ values of duodenal contents were obtained in thirteen patients with duodenal ulcer

\begin{tabular}{|c|c|c|c|c|c|c|c|c|c|c|c|c|c|c|c|c|c|c|c|c|}
\hline \multirow{2}{*}{ Sub- } & \multicolumn{2}{|c|}{$\begin{array}{l}\text { Modified } \\
\text { Ewald } \\
\text { meal* }\end{array}$} & \multicolumn{3}{|c|}{$\begin{array}{c}\text { Stimulation } \\
\text { with } \\
\text { histaminet }\end{array}$} & \multirow{2}{*}{$\begin{array}{c}\text { Num- } \\
\text { ber of } \\
\text { series } \\
\text { of } \\
\text { obser- } \\
\text { vations }\end{array}$} & \multirow{2}{*}{$\begin{array}{c}\text { Total } \\
\text { dura- } \\
\text { tion } \\
\text { in } \\
\text { min- } \\
\text { utes }\end{array}$} & \multicolumn{13}{|c|}{$\begin{array}{l}\text { Percentages of total duration of observations during which various } \mathrm{pH} \text { values } \\
\text { of duodenal contents were obtained }\end{array}$} \\
\hline & $\begin{array}{l}\text { Total } \\
\text { acid- } \\
\text { ity }\end{array}$ & $\begin{array}{l}\text { Free } \\
\text { acid- } \\
\text { ity }\end{array}$ & $\begin{array}{l}\text { Vol- } \\
\text { ume }\end{array}$ & $\begin{array}{c}\text { Total } \\
\text { cc. } \\
\text { tenth } \\
\text { nor- } \\
\text { mal } \\
\mathrm{HCl}\end{array}$ & $\begin{array}{c}\text { est } \\
\text { con- } \\
\text { cen- } \\
\text { tration } \\
\text { free } \\
\mathrm{HCl}\end{array}$ & & & $\begin{array}{c}1.1 \\
\text { to } \\
1.9\end{array}$ & $\begin{array}{c}2 \\
\text { to } \\
2.9\end{array}$ & $\begin{array}{l}\text { Be- } \\
\text { low } \\
3\end{array}$ & $\begin{array}{l}3.0 \\
\text { to } \\
3.9\end{array}$ & $\begin{array}{c}\text { Be- } \\
\text { low } \\
4\end{array}$ & $\begin{array}{l}4.0 \\
\text { to } \\
4.9\end{array}$ & $\begin{array}{c}\text { Be- } \\
\text { low } \\
5\end{array}$ & $\begin{array}{l}5.0 \\
\text { to } \\
5.9\end{array}$ & $\begin{array}{c}\text { Be- } \\
\text { low } \\
6\end{array}$ & $\begin{array}{l}6.0 \\
\text { to } \\
6.9\end{array}$ & $\begin{array}{l}\text { Be- } \\
\text { low } \\
7\end{array}$ & $\begin{array}{l}7.0 \\
\text { to } \\
7.9\end{array}$ & $\begin{array}{l}\text { Be- } \\
\text { low } \\
8\end{array}$ \\
\hline $\begin{array}{r}8 \\
9 \\
10 \\
11 \\
12 \\
13 \\
14 \\
15 \\
16 \\
17 \\
18 \\
19 \\
20\end{array}$ & $\begin{array}{l}52 \\
74 \\
56 \\
44 \\
68 \\
60 \\
80 \\
90 \\
74 \\
78 \\
68 \\
58 \\
74\end{array}$ & $\begin{array}{l}44 \\
64 \\
44 \\
36 \\
56 \\
44 \\
56 \\
84 \\
64 \\
68 \\
58 \\
50 \\
68\end{array}$ & $\begin{array}{r}90 \\
285 \\
220 \\
125 \\
167 \\
270 \\
130 \\
105 \\
190 \\
430\end{array}$ & $\begin{array}{r}58 \\
199 \\
185 \\
80 \\
103 \\
160 \\
101 \\
99 \\
\\
162 \\
304\end{array}$ & $\begin{array}{r}82 \\
84 \\
100 \\
80 \\
100 \\
70 \\
96 \\
104 \\
106 \\
110\end{array}$ & $\begin{array}{l}1 \\
1 \\
2 \\
2 \\
2 \\
1 \\
2 \\
2 \\
1 \\
1 \\
1 \\
2 \\
2\end{array}$ & $\begin{array}{l}180 \\
100 \\
245 \\
328 \\
360 \\
182 \\
362 \\
240 \\
180 \\
180 \\
165 \\
240 \\
316\end{array}$ & \begin{tabular}{|c|}
0 \\
0 \\
36.7 \\
24.4 \\
7.2 \\
24.2 \\
39.3 \\
21.7 \\
57.8 \\
76.7 \\
54.5 \\
93.8 \\
74.8
\end{tabular} & $\begin{array}{c}0 \\
16.0 \\
2.0 \\
20.1 \\
25.5 \\
3.3 \\
17.1 \\
40.8 \\
14.4 \\
10.0 \\
36.4 \\
0 \\
17.7\end{array}$ & \begin{tabular}{|c|}
0 \\
16.0 \\
38.7 \\
44.5 \\
32.7 \\
27.5 \\
56.4 \\
62.5 \\
72.2 \\
86.7 \\
90.9 \\
93.8 \\
92.5
\end{tabular} & $\begin{array}{c}0 \\
14.0 \\
0 \\
6.1 \\
18.3 \\
25.3 \\
10.5 \\
10.8 \\
2.2 \\
3.3 \\
0 \\
0 \\
5.7\end{array}$ & \begin{tabular}{c|}
0 \\
30.0 \\
38.7 \\
50.6 \\
51.0 \\
52.8 \\
66.9 \\
73.3 \\
74.4 \\
90.0 \\
90.9 \\
93.8 \\
98.2
\end{tabular} & $\begin{array}{c}0 \\
26.0 \\
0 \\
11.0 \\
10.6 \\
6.6 \\
9.4 \\
9.2 \\
6.7 \\
7.8 \\
0 \\
0 \\
0.6\end{array}$ & \begin{tabular}{|c|}
0 \\
56.0 \\
38.7 \\
61.6 \\
61.6 \\
59.4 \\
76.3 \\
82.5 \\
81.1 \\
97.8 \\
90.9 \\
93.8 \\
98.8
\end{tabular} & $\begin{array}{c}0 \\
14.0 \\
4.1 \\
23.2 \\
21.7 \\
37.3 \\
9.9 \\
16.7 \\
7.8 \\
2.2 \\
0 \\
0 \\
0.6\end{array}$ & $\begin{array}{c}0 \\
70.0 \\
42.8 \\
84.8 \\
83.3 \\
96.7 \\
\mathbf{8 6 . 2} \\
99.2 \\
88.9 \\
100.0 \\
90.9 \\
93.8 \\
99.4\end{array}$ & \begin{tabular}{|c|}
7.8 \\
30.0 \\
57.2 \\
15.2 \\
13.9 \\
3.3 \\
13.8 \\
0.8 \\
10.0 \\
0 \\
6.1 \\
6.2 \\
0.6
\end{tabular} & $\begin{array}{r}7.8 \\
100.0 \\
100.0 \\
100.0 \\
97.2 \\
100.0 \\
100.0 \\
100.0 \\
98.9 \\
100.0 \\
97.0 \\
100.0 \\
100.0\end{array}$ & \begin{tabular}{|l|}
92.2 \\
0 \\
0 \\
0 \\
2.8 \\
0 \\
0 \\
0 \\
1.1 \\
0 \\
3.0 \\
0 \\
0
\end{tabular} & $\begin{array}{l}100.0 \\
100.0 \\
100.0 \\
100.0 \\
100.0 \\
100.0 \\
100.0 \\
100.0 \\
100.0 \\
100.0 \\
100.0 \\
100.0 \\
100.0\end{array}$ \\
\hline \multicolumn{6}{|c|}{$\begin{array}{l}\text { Averages } 9,11,12,13,14,15,16,17, \\
18,19 \text { and } 20\end{array}$} & $20 \$$ & $3078+$ & 43.12 & 18.30 & 61.42 & 8.75 & 70.17 & 7.99 & 78.16 & 12.13 & 90.29 & 9.08 & 99.37 & 0.63 & 100.0 \\
\hline
\end{tabular}

* Values in clinical units one hour after ingestion of meal.

$\uparrow$ Values obtained in the one-hour period after stimulation.

$\ddagger$ Totals for all thirteen subjects.

gastric secretion and little duodenal secretion. The gross appearance did not change for thirtyfour minutes and during that time the $\mathrm{pH}$ values fluctuated between 1.30 and 2.20. The contents then intermittently contained more duodenal secretion and the $\mathrm{pH}$ values fluctuated wildly between 2.0 and 7.1 for fifty-six minutes, the $\mathrm{pH}$ values at the upper levels not lasting for longer than eight minutes at any one time. During the remainder of the observations the contents recovered appeared to be largely gastric juice and the $\mathrm{pH}$ values remained between 1.10 and 1.5 all the time, with the exception of one period when the values rose to 6.25 for six minutes.

In this, as well as in other observations on patients with duodenal ulcer, the flow of acid gastric material from the tube was not always followed by a fairly prompt flow of amber colored fluid such as was usual in normal persons. In fact, the acid gastric juice was at times recovered almost unmixed with duodenal juice for fairly long periods. This means that the entrance of acid gastric material into the duodenum did not evoke the usual prompt secretory response on the part of

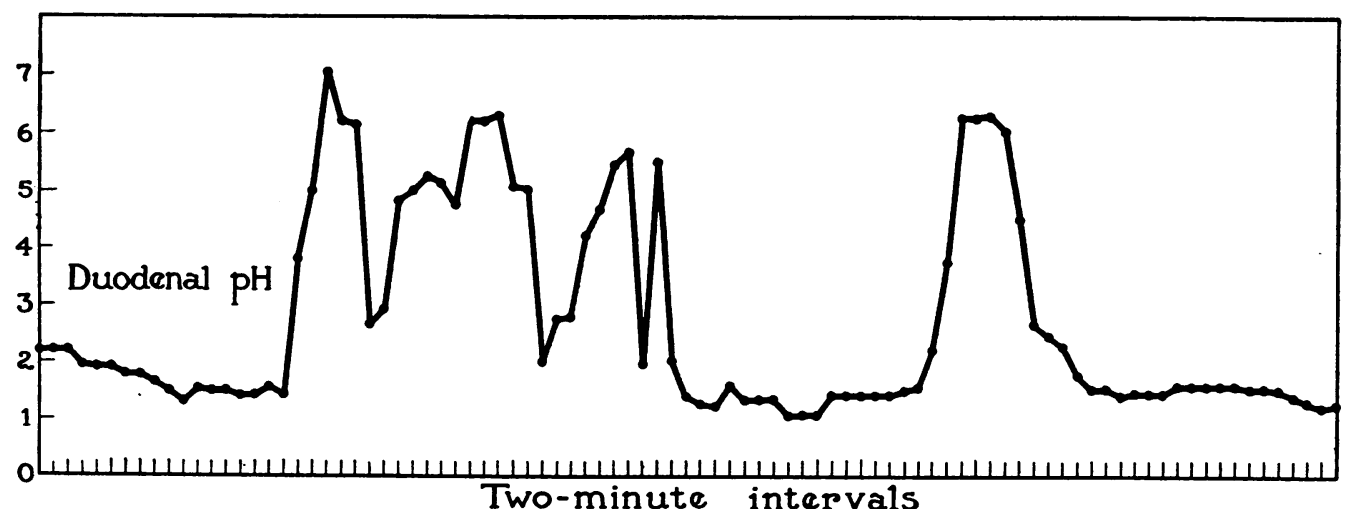

Fig. 2. The Typical Behatior of Values for the Hydrogen Ion Concentration of the Duodenal Contents of Pattents with Duodenal Ulcer 
the liver and pancreas that it did in normal individuals. The frequency and duration of the periods during which acid gastric juice was flowing from the duodenal tube varied considerably, just as in normal persons. However, the excursions to a $\mathrm{pH}$ value below 4 lasted longer than in normal subjects. Of the excursions below a $\mathrm{pH}$ value of 4,53.4, 66.2 and 33.8 per cent lasted ten minutes or less, twenty minutes or less and twentyone minutes or more, respectively. Excursions lasting twenty to thirty minutes occurred nine times, thirty to forty minutes four times, forty to fifty minutes five times, fifty to sixty minutes five times, seventy to eighty minutes twice, eighty to ninety minutes twice, 130 to 140 minutes once and 170 to 180 minutes once.

In some of the series of observations the duration of the periods when $\mathrm{pH}$ values were above 4 was so short that one might more properly speak of excursions above 4 than of excursions below 4 . There was also a distinct tendency for the $\mathrm{pH}$ values to remain in the highly acid side of the range: thus, the $\mathrm{pH}$ values fell below $6,70,80$ and 90 per cent of the time, respectively, in eleven, ten and six of the thirteen cases; below 4 for 50 , 60 and 90 per cent of the time, respectively, in ten, seven and four of the thirteen cases studied.

A $\mathrm{pH}$ value as low as that seen for the acid gastric contents occurred in all but two subjects and for as much as 93.8 per cent of the time. A $\mathrm{pH}$ value below 4 occurred in all but Subject 8; the percentage of the duration of the observations during which $\mathrm{pH}$ values below 4 occurred varied from 30 to 98 .

It appears that in a majority of cases of duodenal ulcer the fasting stomach pours acid into the duodenum during a high percentage of time, and that the outpouring of bile and pancreatic juice may be, but usually is not, in sufficient quantities to raise the $\mathrm{pH}$ values above 6 . It also appears that the secretory response to the entrance of acid may be delayed so that there is little obvious effort on the part of the liver and pancreas to dilute and neutralize the acid for long periods. The duodenal contents remained highly acid a great part of the time.

The widely recognized variability of the response of the gastric secretory mechanisms to stimulation either with the carbohydrate water meal or histamine may explain why no parallelism can be satisfactorily demonstrated in patients with duodenal ulcer between the degrees of secretory activity of the stomach and the behavior of $\mathrm{pH}$ values of the duodenal contents (Table II). Another possible explanation exists, namely, that the capacity for the neutralization of acid by the duodenum varies just as does the amount of acid entering the duodenum. Probably both variables influence the levels of hydrogen ion concentration.

\section{SUMMARY AND CONCLUSIONS}

The $\mathrm{pH}$ values of the duodenal contents removed through duodenal tube by continuous aspiration under negative pressure have been determined under fasting conditions in normal persons and in patients with duodenal ulcer. The $\mathrm{pH}$ values obtained in the fluid removed by tube may not be identical with those of the undisturbed contents because of the continuous removal of the duodenal contents and the shortened period of action of the acid gastric contents on the hormonal mechanisms, but the values may be used for comparative purposes since the same errors would exist in the data obtained from both normal persons and patients with duodenal ulcer.

It may be said that a rough parallelism exists between the degree of gastric secretory activity and the $\mathrm{pH}$ value of the duodenal contents of normal persons : the greater the secretory activity, the lower are the $\mathrm{pH}$ values. The same parallelism cannot be satisfactorily demonstrated in subjects with duodenal ulcer, a fact which suggests that there is a variability in the capacity of the duodenum of patients with duodenal ulcer to neutralize acid entering the duodenum.

The flow of a mixture of amber fluid and acid gastric contents from the tube usually is followed within a few minutes by an increased flow of amber fluid in normal persons, whereas this response is often delayed for varying lengths of time in patients with duodenal ulcer. This suggests that some disturbance of hormonal or chemical mechanism controlling the response of liver and pancreas to the entrance of acid gastric juice into the duodenum exists in some patients with duodenal ulcer.

The behavior of $\mathrm{pH}$ values in patients with duodenal ulcer contrasts with that seen in normal 
persons. The $\mathrm{pH}$ values fell below 6,4 and 2 , respectively, 62, 18 and 3 per cent of the total duration of combined observations on normal persons whose gastric contents contained free hydrochloric acid and below 6,4 and 2, respectively, 90 , 70 and 43 per cent of the duration of combined observations on patients having ulcer in which there was evidence of entrance of acid gastric secretion into the duodenum. The percentage of time during which the $\mathrm{pH}$ values were below 4 (the point at which free hydrochloric acid becomes titrable) was four times and below 2 (values commonly seen in the acid gastric contents) twenty times as great in patients with duodenal ulcer as in normal individuals. Of the excursions of $\mathrm{pH}$ values below 4, 78, 100 and 0 per cent lasted ten minutes or less, twenty minutes or less, and twenty-one minutes or more, respectively, in normal persons with average gastric secretory activity, whereas 53, 66 and 34 per cent of the excursions of $\mathrm{pH}$ values below 4 lasted, respectively, the same length of time in patients with duodenal ulcer.

In short, the $\mathrm{pH}$ values were lower on the average, reached lower levels, and remained there for a longer period in patients with duodenal ulcer than in normal persons. The duodenal mucosa of patients with duodenal ulcer was bathed in a more highly acid fluid for longer periods than in normal persons.

The more highly acid conditions of the duodenal contents in patients with duodenal ulcer appear to be due (1) to larger quantities of acid gastric juice entering the duodenum; (2) to a relative, if not an absolute deficiency of neutralizing and diluting fluid, and (3) to a disturbance of neutralizing and diluting mechanism indicated by delayed appearance of amber colored duodenal contents following the entrance of acid gastric contents into the duodenum.

\section{BIBLIOGRAPHY}

1. Elman, R., and Hartmann, A. F., Spontaneous peptic ulcers of the duodenum after continued loss of total pancreatic juice. Arch. Surg., 1931, 23, 1030.
2. Hoerner, M. T., Peptic ulcer following loss of pancreatic secretion through a fistula: an experimental study. Am. J. Digest. Dis., 1935, 2, 302.

3. Mann, F. C., and Bollman, J. L., The reaction of the content of the gastro-intestinal tract. J. A. M. A., $1930,95,1722$.

4. Mann, F. C., and Williamson, C. S., The experimental production of peptic ulcer. Ann. Surg., 1923, 77, 409.

5. Matthews, W. B., and Dragstedt, L. R., The etiology of gastric and duodenal ulcer; experimental study. Surg., Gynec. and Obst., 1932, 55, 265.

6. Morton, C. B., Observations on peptic ulcer. V. Findings in experimentally produced peptic ulcer: etiologic and therapeutic considerations. Ann. Surg., 1928, 87, 401.

7. Morton, C. B., Peptic ulcer. IX. Chronic lesions of the duodenum following experimentally produced pyloric dysfunction. Arch. Surg., 1934, 28, 467.

8. Cheney, G., and Bloomfield, A. L., Gastric function in cases of gastric and duodenal ulcer. $\mathrm{J}$. Clin. Invest., 1928, 5, 511.

9. Vanzant, F. R., and others, Changes in gastric acidity in peptic ulcer, cholecystitis and other diseases analyzed with the help of new and accurate technic. Arch. Int. Med., 1933, 52, 616.

10. Hume, H. V., and others, Hydrogen ion concentration in the human duodenum. J. Biol. Chem., 1924, 60, 633.

11. Long, J. H., and Fenger, F., On the normal reaction of the intestinal tract. J. Am. Chem. Soc., 1917, 39, 1278.

12. McClendon, J. F., Acidity curves in the stomachs and duodenums of adults and infants, plotted with the the aid of improved methods of measuring hydrogen ion concentration. Am. J. Physiol., 1915, 38, 191.

13. McClure, C. W., Montague, O. C., and Campbell, L. L., The pH and buffer values of duodenal contents derived from normal men. Arch. Int. Med., 1924, 33, 525.

14. McClure, C. W., Functional activities of pancreas and liver. Medical Authors Publishing Company, New York, 1937.

15. Myers, F. J., and McClendon, J. F., Note on the hydrogen ion concentration of the human duodenum. J. Biol. Chem., 1920, 41, 187.

16. Okada, S., and Arai, M., The hydrogen ion concentration of the intestinal contents. J. Biol. Chem., 1922, 51, 135.

17. Morton, C. B., Observations on peptic ulcer. VI. Preliminary report of clinical experiments with gastroduodenal analysis. Am. J. M. Sc., 1929, 177, 65. 